\title{
Kelayakan lokasi budidaya ikan di Danau Tondano ditinjau dari parameter fisika kimia air
}

\author{
Agus I. Kamsuri , N. P. L. Pangemanan, Reiny A. Tumbol
}

\begin{abstract}
The purpose of this study was to determine the current condition of the water quality of Lake Tondano in terms of physical and chemical parameters in a fish farming locations on Lake Tondano waters. Determination of sampling points at each station is placed vertically at three predetermined points from the guard house toward the front of the net, the distance between one point to the next point was $\pm 10 \mathrm{~m}$; whereas for the analysis of water quality parameters was done in Clinical Pathology of Fish Diseases Laboratory, Faculty of Fisheries and Marine Science, Sam Ratulangi Manado and Manado Industrial Research and Standards Laboratory. Determination points were done by purposive sampling which refers to the physiographic location wherever possible in order to represent or describe these waters. The research was carried out for 6 weeks and was done in 2 stages, morning and afternoon. For direct measurement (in situ) was performed once a week which included parameters DO, $\mathrm{pH}$, temperature, and brightness, while the laboratory tests were conducted for 2 weeks which included parameters Nitrite, Nitrate, Iron, Chlorine, Manganese, Chloride, Sulfate, Aluminum, ammonia and Phosphate. The results show that the locations of the four parameters of chlorine $\left(\mathrm{CL}_{2}\right)$ with range $(0.1$ to 0.28$)$ and the parameters of Ammonia with the range $(0.0125$ to 0.15$)$ over the limit indicated on water quality standards. The parameters of temperature, $\mathrm{DO}, \mathrm{pH}$, brightness, nitrate, nitrite, sulfate, manganese, chloride, aluminum, iron and phosphate were still in the water quality standard PP No.82 of 2001.
\end{abstract}

Keywords: Lake Tondano, Aquaculture, Chemical Parameter, Physical Parameter

\section{PENDAHULUAN}

Danau Tondano yang terletak di Kabupaten Minahasa merupakan salah satu sumber daya alam perairan yang sangat strategis dan penting bagi perkembangan perekonomian di Propinsi Sulawesi Utara. Hal ini dapat dilihat dari manfaatnya sebagai sumber bahan pangan (ikan), sumber air minum (PDAM Manado), pengairan sawah, keperluan rumah tangga penduduk sekitar danau, sumber air untuk industri, sumber energi Pembangkit Listrik
Tenaga Air (PLTA), media transportasi dan pariwisata. Saat ini salah satu kegiatan masyarakat yang menonjol di sekitar Danau Tondano adalah memelihara ikan dalam budidaya Karamba Jaring Apung (KJA). Kegiatan tersebut berdampak positif karena dapat meningkatkan pendapatan masyarakat pelaku usaha budidaya dan juga meningkatkan produksi perikanan di Kabupaten Minahasa. Selain berdampak positif, jika berkembang tanpa kendali kegiatan KJA ini bisa menimbulkan dampak negatif karena 
kegiatan tersebut menghasilkan limbah organik (terutama pencemaran unsur nitrogen dan fosfor) yang besar akibat pemberian pakan yang tidak efisien sehingga sisa pakan dan kotoran ikan akan menumpuk di dasar perairan (Mamangkey dan Soeroto, 2013).

Daya dukung Danau Tondano semakin hari semakin menurun, fakta ini didukung oleh beberapa masalah yang teridentifikasi sebagai berikut : terjadi pendangkalan danau, menurunya kualitas air, melimpahnya tumbuhan air, meningkatnya jumlah usaha pemeliharaan ikan dalam jaring tancap, resultan dari semua masalah ini dapat mempengaruhi keberadaan ikan-ikan yang hidup di danau (Tuapatel 2008 dalam Kambey 2011). Seiring dengan meningkatnya kegiatan Budidaya di Danau Tondano yang mempengaruhi kualitas air, maka perlu dilakukan penelitian untuk mengetahui tentang kondisi parameter fisika dan kimia perairan lokasi budidaya ikan di Danau Tondano.

\section{BAHAN DAN METODE}

\section{Tempat Penelitian}

Penelitian ini dilaksanakan di Laboratorium Lingkungan dan Kualitas Air, Laboratorium Patologi dan Klinik Penyakit Ikan Fakultas Perikanan dan Ilmu Kelautan dan Balai Riset dan Standarisasi Industri Manado. Sedangkan pengukuran parameter kualitas air dan pengambilan sampel dilakukan secara langsung (in situ) dibeberapa tempat yang mewakili aktivitas budidaya yaitu : desa Eris,desa Toulimembet, desa Leleko dan Kelurahan Paleloan. Waktu penelitian direncanakan selama 6 (enam) minggu, mulai dari bulan Maret 2013 sampai bulan April 2013.

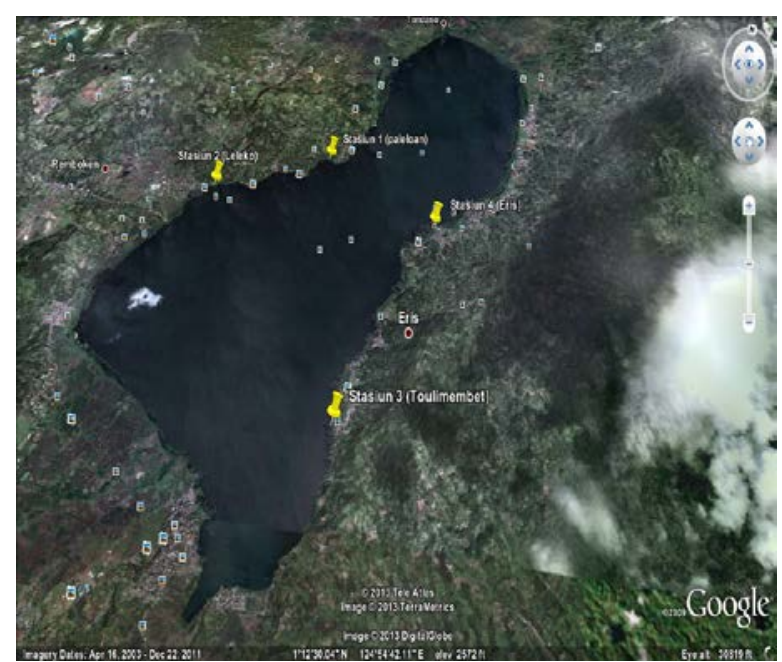

Gambar 1. Peta Lokasi Penelitian

\section{Teknik Pengambilan Sampel}

Penentuan titik pengambilan sampel dilakukan secara purposive (Nasution, 2001) yang mengacu pada fisiografi lokasi agar sedapat mungkin biasa mewakili atau menggambarkan perairan tersebut. Pengukuran secara langsung (in situ) dalam penelitian ini dilakukan sebanyak 1 kali dalam seminggu, dimulai dari minggu pertama sampai minggu ke tujuh (6 kali pengukuran), untuk pengukuran $(\mathrm{pH}, \mathrm{DO}$, suhu, dan Kecerahan) dan dilakukan dalam 2 tahap yaitu : pada pagi hari, dan sore hari dilaksanakan pada 4 lokasi yang berbeda antara lain di desa Eris, Kelurahan Paleloan, desa Toulimembet, dan desa Leleko. Pengukuran secara langsung pada setiap stasiun dilakukan secara vertikal pada tiga titik, dari arah rumah jaga tegak lurus sampai pada kurungan jaring paling depan dengan jarak antara titik satu ke titik yang berikutnya $\pm 10 \mathrm{~m}$.

Pengambilan Sampel air untuk analisis di Laboratorium (Nitrit, Nitrat, Besi, Klorin, Mangan, Klorida, Sulfat, Alumunium, Amoniak dan Fosfat) di ambil dengan menggunakan botol sampel. 
Pengambilan sampel dilaksanakan 1 kali dalam 2 minggu selama 6 minggu waktu penelitian, botol yang berisi air sampel dimasukan kedalam cool box yang berisi es batu. Pengambilan sampel ini di lakukan pada sore hari di ke empat titik seperti yang dijelaskan di atas, kemudian sampel air langsung dibawa ke Laboratorium Patologi dan Klinik Penyakit Ikan Fakultas Perikanan dan Ilmu Kelautan Universitas Sam Ratulangi Manado dan Balai Riset dan Standarisai Industri Manado untuk di analisis.

\section{Analisis Sampel}

Pengukuran parameter kualitas air pada penelitian ini dilakukan dalam dua metode yaitu, pengukuran secara langsung (in situ) dan analisis laboratorium. Dimana pengukuran secara langsung (in situ) meliputi : DO, suhu, pH, dan Kecerahan sedangkan analisis Laboratorium yaitu : Nitrit, Nitrat, Besi, Klorin, Mangan, Klorida, Sulfat, Amoniak, Sulfat dan Alumunium.

Berdasarkan panduan pengujian kualitas air sumber dan limbah cair, (Standart Nasional Indonesia 1994 dalam Khartiono, 2008) kegiatan pengujian meliputi :

1. Pemeriksaan unsur-unsur yang dapat merubah dengan cepat, dilakukan langsung di lapangan setelah pengambilan contoh.

2. Untuk pemeriksaan sampel air, sebelum dibawa ke laboratorium, botol ditutup dengan rapat dan dimasukan ke dalam kantong plastik kemudian di simpan ke dalam kool box.

3. Semua hasil pemeriksaan dicatat dalam buku cataan khusus yang meliputi nama sumber air, tanggal pengambilan contoh dan nama pemeriksa.

\section{Parameter yang diukur secara langsung (in situ)}

\section{Oksigen Terlarut}

DO meter dicelupkan langsung ke dalam air.

- Tekan tombol ON.

- Ditunggu beberapa saat hingga angka dilayar stabil (tidak berubah)

\section{pH}

- $\mathrm{pH}$ meter dicelupkan langsung ke dalam air.

- Tekan tombol ON.

- Ditunggu beberapa saat hingga angka pada layar stabil (tidak berubah).

\section{Suhu}

- Termometer digital dicelupkan langsung ke dalam air.

- Tekan tombol ON.

- Ditunggu beberapa saat hingga angka pada layar stabil (tidak berubah).

\section{Kecerahan}

- Menggunakan alat secchi disk.

- Secchi disk dimasukan perlahan lahan ke dalam air.

- Pertahankan posisi lurus ke dalam perairan sampai bulatan putih hitam berwarna hitam semua atau putih semua.Warna hitam yang mewakili warna gelap dan putih mewakili warna cerah. 


\section{Analisis di Laboratorium}

Analisis laboratorium dilakukan untuk pengukuran : Nitrit $\left(\mathrm{NO}_{2}\right)$, Nitrat $\left(\mathrm{NO}_{3}\right)$, Besi $(\mathrm{Fe})$, Klorin $\left(\mathrm{Cl}_{2}\right)$, Mangan $(\mathrm{Mn})$, Klorida $(\mathrm{Cl})$, Sulfat $\left(\mathrm{SO}_{4}\right)$, dan Alumunium (Al). Teknik pengujian berdasarkan buku panduan penggunaan alat Water Test Kit InScienPro AYI-10 yaitu sebagai berikut :

\section{Nitrit $\left(\mathrm{NO}_{2}\right)$}

Untuk mengukur parameter Nitrat dengan cara :

- Masukan sampel ke dalam tabung cell sebanyak $5 \mathrm{ml}$,

- Homogenkan sampel larut,

- Reaksikan selama 10 menit,

- Lalu masukan cell test ke dalam spectrophoto meter sampai tepat masuk ke dalamnya. Sejajarkan tanda garis ke derajatnya pada photometer,

- Masukan kode parameter $\mathrm{NO}_{2}$ 031,

- Mulai pengukuran,

- Hasil yang diperoleh dapat dilihat pada layar spectrophoto meter,

- Setelah dilakukan pembacaan warna larutan sampel akan tetap stabil selama 60 menit.

\section{Nitrat $\left(\mathrm{NO}_{3}\right)$}

Untuk mengukur parameter Nitrat dilakukan dengan cara :

- Tambahkan 1 takar microspoon biru NO3-1AK ke dalam tabung uji, tutup dengan penutup ulir,

- Homogenkan dan reaksikan selama 2 menit,

- Tambahkan $1.5 \mathrm{ml}$ sampel dengan pipet dengan perlahan, tutup dengan penutup ulir dan campur. Perhatian, tabung akan menjadi sangat panas,

- Reaksikan selama 5 menit,

- Lalu masukan cell test ke dalam spectrophoto meter sampai tepat masuk ke dalamnya. Sejajarkan tanda garis ke derajatnya pada photometer,

- Masukan kode parameter $\mathrm{NO}_{3}$ 030,

- Mulai pengukuran,

- Hasil yang diperoleh dapat dilihat pada layar spectrophoto meter,

- Setelah dilakukan pembacaan warna larutan sampel akan tetap stabil selama 60 menit.

\section{Besi (Fe)}

Untuk mengukur parameter Besi dilakukan dengan cara :

- Siapkan tabung cell lalu masukan $5.0 \mathrm{ml}$ sampel,

- Tambahkan 1 takar microspoon biru Fe-1AK, tutup dengan penutup ulir,

- Guncangkan cell dengan kencang untuk melarutkan padatan,

- Reaksikan selama 3 menit,

- Lalu masukan cell test ke dalam spectrophoto meter sampai tepat masuk ke dalamnya. Sejajarkan tanda garis ke derajatnya pada photometer,

- Masukan kode parameter Fe 037,

- Mulai pengukuran,

- Hasil yang diperoleh dapat dilihat pada layar spectrophoto meter,

- Setelah dilakukan pembacaan warna larutan sampel akan tetap stabil selama 60 menit. 


\section{$\operatorname{Klorin}\left(\mathrm{Cl}_{2}\right)$}

Untuk mengukur parameter Klorin dilakukan dengan cara :

- Siapkan tabung cell lalu masukan $5.0 \mathrm{ml}$ sampel,

- Tambahkan 1 takar microspoon biru $\mathrm{Cl}_{2}-1$, tutup dengan penutup ulir,

- Guncangkan cell dengan kencang untuk melarutkan padatan,

- Reaksikan selama 3 menit,

- Lalu masukan cell test ke dalam spectrophoto meter sampai tepat masuk ke dalamnya. Sejajarkan tanda garis ke derajatnya pada photometer,

- Masukan kode parameter $\mathrm{Cl}_{2}$ 141,

- Mulai pengukuran,

- Hasil yang diperoleh dapat dilihat pada layar spectrophoto meter,

- Setelah dilakukan pembacaan warna larutan sampel akan tetap stabil selama 30 menit.

\section{Mangan (Mn)}

Untuk mengukur parameter Mangan dilakukan dengan cara :

- Masukan sampel sebanyak $7.0 \mathrm{ml}$ kedalam tabung cell test,

- Tambahkan 2 tetes $\mathrm{Mn}-1 \mathrm{k}$, tutup tabung dengan penetup ukir, campur, dan reaksikan selama 2 menit,

- Tambahkan 3 tetes Mn-2K, tutup tabung dengan penutup ulir dan reaksikan selama 5 menit,

- Lalu masukan cell test ke dalam spectrophoto meter sampai tepat masuk ke dalamnya. Sejajarkan tanda garis ke derajatnya pada photometer,

- Masukan kode parameter Mn 159,

- Mulai pengukuran,

- Hasil yang diperoleh dapat dilihat pada layar spectrophoto meter,

- Setelah dilakukan pembacaan warna larutan sampel akan tetap stabil selama 60 menit.

\section{Klorida (Cl)}

Untuk mengukur parameter Klorida dilakukan dengan cara :

- Siapkan tabung cell lalu masukan dengan pipet $0.50 \mathrm{ml} \mathrm{Cl-1K}$ ke dalam tabung uji, tutup dengan tutup ulir, dan campur.

- Tambahkan $1.0 \mathrm{ml}$ sampel dengan pipet, tutup dengan penutup ulir, dan campur,

- Lalu masukan cell test kedalam spectrophoto meter sampai tepat masuk ke dalamnya. Sejajarkan tanda garis ke derajatnya pada photometer,

- Masukan kode parameter $\mathrm{Cl}$ 095,

- Mulai pengukuran,

- Hasil yang diperoleh dapat dilihat pada layar spectrophoto meter,

- Setelah dilakukan pembacaan warna larutan sampel akan tetap stabil selama 30 menit dan akan meningkat sebesar 5\%.

\section{Sulfat $\left(\mathrm{SO}_{4}\right)$}

Untuk mengukur parameter Sulfat dilakukan dengan cara :

- Siapkan tabung cell lalu masukan $2.0 \mathrm{ml}$ sampel, 
- Tambahkan 1 takar microspoon biru $\mathrm{SO}_{4}-1 \mathrm{~K}$ dan tutup dengan penutup ulir.

- Guncangkan cell dengan kencang untuk melarutkan padatan dan reaksikan selama 2 menit,

- Lalu masukan cell test kedalam spectrophoto meter sampai tepat masuk ke dalamnya. Sejajarkan tanda garis ke derajatnya pada photometer,

- Masukan kode parameter $\mathrm{SO}_{4} 154$,

- Mulai pengukuran,

- Hasil yang diperoleh dapat dilihat pada layar spectrophoto meter.

- Setelah dilakukan pembacaan warna larutan sampel akan tetap stabil selama 60 menit.

\section{Alumunium (Al)}

Untuk mengukur parameter Alumunium dilakukan dengan cara :

- Siapkan air sampel dengan $\mathrm{pH}$ berada pada kisaran spesifik 3-10, jika perlu tambahkan larutan sodium hidroksida atau asam sulfat encer tetes demi tetes untuk mengatur $\mathrm{pH}$,

- Ambil sampel sebanyak $6 \mathrm{ml}$ lalu masukan ke dalam tabung cell lalu kocok,

- Tambahkan 1 takar sendok microspoon biru Al-1K kedalam uji. Tutup tabung uji dengan rapat, dan kocok sampai semua reagent terlarut,

- Tambahkan $0.25 \mathrm{ml} \mathrm{Al-2K}$ dengan pipet dan campur, diamkan selama 5 menit agar reagent bereaksi kemudian lakukan pengetesan,
- Masukan cell test ke dalam spectrophoto meter sampai tepat masuk ke dalamnya. Sejajarkan tanda garis ke derajatnya pada photometer,

- Masukan kode parameter Al 196,

- Mulai pengukuran,

- Hasil yang diperoleh dapat dilihat pada layar spectrophoto meter,

- Setelah dilakukan pembacaan warna larutan sampel akan tetap stabil selama 15 menit.

\section{Amoniak}

Untuk mengukur parameter Amoniak dilakukan dengan cara :

- Nyalakan alat kemudian tekan Hach Programs pada panel,

- Pilih 380 N, Amonia, Ness lalun tekan start,

- Masukan $25 \mathrm{ml}$ air sampel ke dalam tabung reaksi,

- Tambahkan $25 \mathrm{ml}$ air bersih sebagai larutan blanko,

- Masukan 3 tetes mineral stabilizer pada tiap botol lalu campurkan masing-masing botol,

- Masukan lagi Polovinil alcohol pada tiap botol lalu campurkan,

- Kemudian pipet $1,0 \mathrm{ml}$ reagen Nassler pada tiap botol lalu campurkan,

- Tekan timer lalu tekan OK,

- Tunggu selama 1 menit,

- Tuangkan kedua botol sampel ke dalam botol pereaksi,

- Ketika tanda dari alat berbunyi, maka masukan larutan blanko ke dalam alat spektrofotometer kemudian tekan zero lalu keluarkan lagi, 
- Masukan larutanair sampel kemudian tekan reed,

- Hasil akan muncul pada layar dengan angka digital.

\section{Fosfat $\left(\mathrm{PO}_{4}\right)$}

Untuk mengukur parameter Fosfat dilakukan dengan cara :

- Sampel air di pipet sebanyak $2 \mathrm{ml}$ kemudian dimasukan ke dalam tabung reaksi

- Ditambahkan $2 \mathrm{ml}$ asam aborat $1 \%$

- Selanjutnya ditambahkan $3 \mathrm{ml}$ larutan pengoksid,

- Dikocok dan dibiarkan selama 1 jam sehingga terjadi warna biru dan dianalisis pada spektofotometer. Kepekeen warna tergantung pada panjang gelombang $650 \mathrm{~nm}$ (absorbance),

- Perhitungan : Ortofosfat $=$ Pot $(0,09+19,11) \times$ Abs. tabel $\mathrm{p}=\mathrm{PO}_{4}$ $\mathrm{x} 2,3$.

\section{Analisis Data}

Data yang diambil dan dikumpulkan dalam penelitian ini adalah parameter kualitas air yang meliputi peubah fisik (suhu dan kecerahan) dan kimia (DO, pH, nitrit, nitrat, besi, klorida, mangan, klorin, sulfat, dan alumunium).

Data yang diperoleh dianalisis secara deskriptif dengan membuat tabulasi grafik dan tabel dengan membandingkan baku mutu air yaitu Peraturan Pemerintah Nomor 82 Tahun 2001 tentang Pengelolaan Kualitas Air dan Pengendalian Pencemaran Air, dan literatur-literatur yang berkaitan dengan kualitas air untuk kegiatan budidaya ikan di perairan tawar.

\section{HASIL DAN PEMBAHASAN}

\section{Parameter Fisika}

Suhu

Kisaran suhu optimal bagi kehidupan ikan di perairan tropis adalah antara $28^{0} \mathrm{C}-32^{0} \mathrm{C}$. Pada kisaran tersebut konsumsi oksigen mencapai 2,2 mg/g berat tubuh/jam. Dibawah suhu $25^{\circ} \mathrm{C}$, konsumsi oksigen mencapai $1,2 \mathrm{mg} / \mathrm{g}$ berat tubuh/jam. Pada suhu $12-18^{0} \mathrm{C}$ mulai berbahaya bagi ikan, sedangkan di bawah $12^{\circ} \mathrm{C}$ ikan tropis mati kedinginan. Secara teoritis, ikan tropis masih hidup normal pada suhu $30-35^{\circ} \mathrm{C}$ apabila konsentrasi oksigen terlarut cukup tinggi (Kordi dan Tancung, 2005)

Suhu adalah parameter fisika yang dapat dipengaruhi oleh kecerahan dan kedalaman. Air yang dangkal dan daya tembus matahari yang tinggi dapat meningkatkan suhu perairan (Anonimous, 2008). Berdasarkan baku mutu kualitas air menurut PP No. 82 Tahun 2001 untuk suhu adalah deviasi 3 dari keadaan alami. Hasil pengukuran diempat lokasi menunjukan bahwa suhu berada pada kisaran antara 24,5-29,9 ${ }^{\circ} \mathrm{C}$. Dimana nilai terendah $\left(24,5^{\circ} \mathrm{C}\right)$ berada di Kelurahan Paleloan pada minggu ke 2 bulan Maret di titik I pada waktu pagi dan $\left(29,9^{\circ}\right)$ nilai tertinggi, berada di desa Eris pada minggu 1 bulan April di titik II pada waktu pagi.

\section{Kecerahan}

Nilai kecerahan dinyatakan dalam satuan meter. Nilai ini sangat dipengaruhi oleh keadaan cuaca, waktu pengukuran, kekeruhan, dan padatan yang tersuspensi, serta ketelitian orang yang melakukan pengukuran. Pengukuran kecerahan sebaiknya dilakukan pada saat cuaca cerah (Effendi, 2003). 
Dari hasil pengukuran secara langsung di lapangan, dari keempat lokasi di atas diperoleh nilai terendah 1,1 m berada pada titik II desa Toulimembet di minggu pertama Bulan april. Sedangkan nilai tertinggi 2,5 m berada pada tiga lokasi yang berbeda yaitu Kelurahan Paleloan, desa Toulimembet dan desa Eris. Secara umum nilai yang diperoleh dari keempat lokasi diatas berada dalam kondisi alami, dimana kecerahan yang baik bagi usaha budidaya ikan dan udang berkisar antara 30-40 cm (Kordi dan Tancung, 2005).

\section{Parameter Kimia}

\section{Derajat Keasaman (pH)}

Nilai pH menggambarkan seberapa besar tingkat keasaman atau kebasaan suatu perairan. Tingkat keasaman merupakan faktor yang penting dalam proses pengolahan air untuk perbaikan kualitas air. Kondisi perairan bersifat netral apabila nilai $\mathrm{pH}$ sama dengan 7 , kondisi perairan bersifat asam bila $\mathrm{pH}$ kurang dari 7, sedangkan $\mathrm{pH}$ lebih dari 7 kondisi perairan bersifat basa (Irianto dan Triweko, 2011).

Dari hasil pengukuran secara langsung di lapangan pada empat lokasi diatas, nilai tertinggi yang diperoleh keseluruhanya masih berada pada batas standar baku mutu PP No. 82 Tahun 2001. Menurut (Kordi dan Tancung, 2005) usaha budidaya perairan akan berhasil baik dengan $\mathrm{pH}$ 6,5-9,0. Nilai $\mathrm{pH}$ tertinggi di keempat lokasi ini cenderung terjadi pada pagi hari, hasil pengukuran terendah berada pada desa Toulimembet berkisar antara 7,1-9,3 dimana nilai 7,1 terdapat pada titik I minggu ke dua bulan Maret pada pagi hari dan nilai 9,3 terdapat pada titik yang sama minggu pertama bulan
April pada pagi hari. Sedangkan pengukuran tertinggi berada pada desa Leleko yang berkisar antara 7,5-9,97, dimana nilai 7,5 terdapat pada titik II minggu ke dua bulan April pada pagi hari dan nilai 9,97 terdapat pada titik, minggu dan bulan yang sama pada sore hari.

\section{Oksigen Terlarut (DO)}

Oksigen terlarut pada desa Eris tidak berada pada kondisi alami yaitu pada batas minimum $<3 \mathrm{mg} / \mathrm{L}$ mengacu pada Baku Mutu Air PP. No. 82 Tahun 2001. Nilai kandungan oksigen tertinggi yaitu 5,25 dan nilai terendah 2,1. Hal ini didukung oleh pernyataan (Kordi dan Tancung, 2005) yang menyatakan bahwa jumlah oksigen yang dibutuhkan untuk pernapasan biota budidaya tergantung ukuran, suhu dan tingkat aktivitasnya dan batas minimumnya adalah 3 ppm atau 3 $\mathrm{mg} / \mathrm{L}$.

Dari hasil pengukuran di Lokasi IV (desa Eris) nilai DO tertinggi berada pada titik I pada waktu pagi hari di minggu ke 3 (tiga) bulan Maret dan nilai taerendah berada pada titik II pada waktu pagi hari di minggu ke-3 (Tiga) bulan Maret. Kekurangan kandungan oksigen pada lokasi IV ini dikarnakan padatnya jaring tancap yang tidak terkontrol milik para petani budidaya, selain itu di sekitar lokasi budidaya terdapat banyak tumbuhan air seperti eceng gondok yang berkompetisi menyerap kandungan oksigen dalam air untuk proses respirasi.

\section{Nitrat $\left(\mathrm{NO}_{3}\right)$}

Nitrat $\left(\mathrm{NO}_{3}\right)$ adalah bentuk utama nitrogen di perairan alami dan merupakan nutrien utama bagi pertumbuhan tanaman dan alga. Nitrat merupakan salah satu sumber utama nitrogen di perairan. Kadar nitrat pada perairan alami tidak pernah 
lebih dari 0,1 mg/liter. Kadar nitrat lebih dari 5 mg/liter menggambarkan terjadinya pencemaran antropogenik yang berasal dari aktivitas manusia dan tinja hewan (Notodarmojo, 2005).

Dari hasil analisis di laboratorium nilai yang diperoleh dari keempat lokasi yang berbeda, dengan dibandingkan baku mutu PP No. 82 Tahun 2001 masih berada pada kondisi alami. Dimana diperoleh nilai sebagai berikut : Kelurahan Paleloan (0,10,23), desa Leleko (0,1-0,31), desa Toulimembet $(0,1-0,09)$, desa Eris $(0,01$ 0,14). Apabila kadar nitrat dibawah 0,1 atau diatas $4,5 \mathrm{mg} / \mathrm{l}$, merupakan faktor pembatas (Notodarmojo, 2005).

\section{Nitrit $\left(\mathrm{NO}_{2}\right)$}

Nitrit $\left(\mathrm{NO}_{2}\right)$ beracun terhadap udang dan ikan karena mengoksidasi $\mathrm{Fe}^{2+}$ di dalam hemoglobin. Akumulasi nitrit di dalam tambak dan kolam diduga terjadi sebagai akibat tidak seimbangnya antara kecepatan perubahan dari nitrit menjadi nitrat dan dari amonia menjadi nitrit. Persyaratan kadar nitrit untuk air tambak dan kolam tidak boleh lebih besar dari 0,5 ppm (Kordi dan Tancung, 2005).

Dari hasil analisis laboratorium diperoleh nilai sebagai berikut : Kelurahan Paleloan (0,014-0,027), desa Leleko (0,020,024), desa Toulimembet $(0,013-0,018)$ dan desa Eris (0,012-0,094). Jika dibandikan dengan standar baku mutu 0,06 nilai di keempat lokasi ini masih tergolong alami untuk kriteria budidaya ikan air tawar.

\section{Sulfat $\left(\mathrm{SO}_{4}\right)$}

Senyawa sulfat adalah senyawa yang memang umum berada dalam badan air, ion sulfat biasanya bias ditemukan dalam kosentrasi yang bervariasi dalam air.
Senyawa sulfur organik baik itu dalam bebas maupun keberadaanya sebagai polutan umumnya terdapat di system perairan alam. Degradasi dari komponennya merupakan salah satu proses microbial yang sangat penting.

Jika dibandingkan dengan baku mutu PP No.82 Tahun 2001 dengan hasil analisis laboratorium, nilai yang diperoleh masih dalam kondisi alami dimana hasil yang diperoleh yaitu : Kelurahan Paleloan (15-30), desa Leleko (12-19), desa Toulimembet (11-14) dan desa Eris (1114) maka dapat simpulkan hasil analisis masih dalam kondisi alami.

\section{Mangan (Mn)}

Mangan (Mn) adalah kation logam yang memiliki karakteristik kimia serupa dengan besi. Mangan berada dalam bentuk manganous $\left(\mathrm{Mn}^{2+}\right)$ dan manganik $\left(\mathrm{Mn}^{4+}\right)$. Pada perairan dengan kondisi anaerob akibat dekomposisi bahan organik dengan kadar yang tinggi, $\mathrm{Mn}^{4+}$ pada senyawa mangan dioksida mengalami reduksi menjadi $\mathrm{Mn}^{2+}$ yang bersifat larut. Kadar mangan pada perairan alami sekitar 0,2 mg/l atau kurang, sedangkan kadar yang lebih besar dapat terjadi pada air tanah dalam dan pada danau yang dalam (Effendi, 2003).

Dari hasil analisis laboratorium diperoleh hasil sebagai berikut : Kelurahan Paleloan $(0,2-0,23)$, desa Leleko (0,12$0,23)$, desa Toulimembet $(0,02-0,09)$ dan desa Eris $(0,1-0,15)$. Berdasarkan baku mutu air kondisi perairan di empat lokasi ini masih berada pada kondisi alami, maka dapat disimpulkan bahwa hasil analisis mangan masih berada pada kisaran yang baik untuk pertumbuhan ikan.

\section{Klorida (CI)}


Tinjauan dari baku mutu air kelas III PP No. 82 kelas III Tahun 2001, bagi kegiatan perikanan parameter Klorida tidak memiliki standar yang baku atau tidak dipersyaratkan. Dari hasil analisis hasil yang ditunjukan di keempat lokasi adalah sebagai berikut : Kelurahan Paleloan (2022), desa Leleko (19-26), desa Toulimembet (13-29,6), dan desa Eris (1629).

Menurut (Davis dan Cornwell, 1991 dalam Effendi, 2003) perairan yang diperuntukan bagi keperluan domestik, termasuk air minum, pertanian, dan industri sebaiknya memiliki kadar klorida lebih kecil dari 100 mg/L.

\section{Klorin $\left(\mathrm{Cl}_{2}\right)$}

Klorin digunakan dalam bentuk klorin bebas atau hipoklorit. Kedua unsur ini berfungsi sebagai potensial agen oksidasi. Korin bereaksi dengan air membentuk hipoklorous dan asam hipoklorik sesuai reaksi. Pada konsentrasi yang lebih tinggi, oksidasi dinding sel akan memusnahkan organisme tersebut. Beberapa faktor yang mempengaruhi hal ini antara lain bentuk klor, $\mathrm{pH}$, konsentrasi, waktu kontak, tipe organisme, dan temperatur

(jujubandung.com/.../parameter-fisika-

kimia-biolog... - download 14 februari 2013). Berdasarkan baku mutu air PP No. 82 Tahun 2001 standar untuk nilai klorin yaitu $0,03 \mathrm{mg} / \mathrm{L}$ sedangkan hasil analisis menunjukan nilai yang lebih tinggi dari standar baku mutu dimana hasil tersebut adalah sebagai berikut : Kelurahan Paleloan (0,11-0,28), desa Leleko (0,1$0,17)$, desa Toulimembet $(0,07-0,19)$ dan desa Eris (0,09-0,096).

\section{Alumunium (Al)}

Aluminium merupakan unsur terbanyak ketiga dalam kerak bumi Kebanyakan alumunium yang dibawa air sebagai partikel-partikel mineral mikroskopik yang tersuspensi. Konsentrasi dari almunium dalam kebanyakan air kemungkinan kurang dari 1,0 mg/l file:///E:/Literatur/Aluminium\%20\%20Wik ipedia\%20bahasa\%20Indonesia,\%20ensikl opedia\%20bebas.htm (Download 14 februari 2013) .

Dari tinjauan Baku mutu air PP No. 82 Tahun 2001, untuk parameter alumunium tidak dipersyaratkan atau tidak memiliki standar yang baku sebagai acuan. Berdasarkan hasil analisis di empat lokasi yang berbeda menunjukan hasil sebagai berikut : Kelurahan Paleloan (0-018), desa Leleko (0,1-0,013), desa Toulimembet $(0,03-0,12)$ dan desa Eris $(0,02-0,08)$. Hasil ini jika dibandingkan dengan pernyataan (Effendi, 2003) yang menyatakan bahwa perairan alami biasanya memiliki kandungan aluminium kurang dari 1,0 mg/l maka hasil tersebut masih dalam kondisi alami.

\section{Besi (Fe)}

Adanya kandungan besi (Fe) dalam air menyebabkan warna air tersebut berubah menjadi kuning-cokelat setelah beberapa saat kontak dengan udara. Besi dalam air biasanya terlarut dalam bentuk senyawa atau garam Karbonat, garam sulfat, hidroksida dalam bentuk koloid atau dalam keadaan bergabung dengan senyawa organik. Proses oksidasi dan reduksi besi biasanya melibatkan bakteri sebagai mediator. Bakteri komosintesis Thiobacillus dan Ferrobaccilus mamiliki sistem enzim yang dapat mentrasfer 
elektron dari ion ferro kepada oksigen (Pacini et al, 2005).

Dari hasil analisis laboratorium di Kelurahan Paleloan parameter besi berkisar antara $(0,02-0,17)$, di desa Leleko $(0,1-0,16)$, di desa Toulimembet $(0,02-$ 0,06), dan di desa Eris parameter besi berkisar antara $(0,02-0,08)$. Pada baku mutu air kelas III nilai besi tidak memiliki standar yang baku, menurut (effendi, 2003) kadar besi pada perairan alami berkisar antara 0,05-0,2 mg/l. Maka dari hasil diatas dapat disimpulkan bahwa perairan masih dalam kondisi alami.

\section{Amonia}

Didalam perairan amonia terdapat dalam dua bentuk, yaitu $\mathrm{NH}^{4+}$ atau bisa disebut lonized Ammonia (Terionisasi) yang kurang beracun dan $\mathrm{NH}_{3}$ atau Unionized Ammonia (tidak terionisasi) yang beracun. Kedua bentuk amonia dalam air tersebut berada dalam keseimbangan (Kordi, 2009).

Untuk parameter amonia tidak dipersyaratkan atau belum adanya nilai standar yang baku. Amonia bebas yang tidak terionisai pada perairan sebaiknya tidak lebih dari 0,02 mg/L. Dari hasil analisis nilai tertinggi berada pada desa Eris (0,15-0,1195), desa Leleko (0,040,0125), Kelurahan Paleloan (0,03-0,0195) dan nilai terendah berada pada desa Toulimembet (0,02-0,0355). Nilai amonia yang ada pada keempat Kecamatan diatas telah melewati batas untuk kriteria perairan budidaya. Hal ini disebabkan banyaknya pasokan bahan organik yang mengalir melalui aliran sungai yang masuk ke danau, juga penggunaan pakan yang tidak efisien sehingga mencemari perairan sekitar lokasi budidaya. Padat tebar juga tidak menutup kemungkinan meningkatnya

$\begin{array}{lrrr}\text { amoniak karena hasil buangan } \\ \begin{array}{l}\text { metabolisme dari } \\ \text { dibudidayakan. }\end{array} & & \text { biota } & \text { yang } \\ & & \end{array}$

\section{- Fosfat $\left(\mathrm{PO}_{4}\right)$}

Senyawa organik fosfat dalam danau umumnya berada dalam bentuk ion asam fosfat, yang merupakan hasil dari dekomposisi organisme yang sudah mati. Kandungan fosfat diperairan alami, umumnya tidak lebih dari 0,1 mg/L (Hutagalung, 1997). Untuk standar baku mutu PP No. 82 Tahun 2001 nilai fosfat berada pada $1 \mathrm{mg} / \mathrm{L}$, dari hasil analisis loboratorium yang dibandingkan dengan standar baku mutu dapat dinyatakan bahwa nilai yang diperoleh dari empat lokasi penelitian dimana, Kelurahan Paleloan $(0,00-0,15)$, desa Leleko $(0,00-0,001)$, desa Toulimembet $(0,00-0,028)$ dan desa Eris (0,00-0,018) masih dalam batas alamiah suatu perairan.

\section{KESIMPULAN}

Dari hasil penelitian penukuran secara langsung (in situ) dan analisis di laboratoriun diempat lokasi, parameter klorin dan amoniak melewati batas baku mutu kualitas air. Sedangkan parameter suhu, kecerahan, $\mathrm{pH}, \mathrm{DO}$, nitrat, nitrit, sulfat, mangan, klorida, alumunium, besi dan fosfat dianggap memenuhi kriteria budidaya setelah dibandingkan dengan baku mutu air PP No. 82 Tahun 2001 dan beberapa literatur kualitas air untuk menunjang kegiatan budidaya.

\section{UCAPAN TERIMA KASIH}

Disampaikan ucapan terima kasih kepada Laboratorium dan Patologi dan Klinik penyakit Ikan Usrat dan stasiun 
karamba jaring apung Balai Budidaya Air Tawar Tatelu yang telah memfasilitasi penyediaan peralatan yang dipakai dan lokasi penelitian.

\section{DAFTAR PUSTAKA}

Anonimous 2001. Identifikasi Desa Sampel Perikanan di Sulawesi Utara. Kerja Sama FPIK UNSRAT dan Dinas Perikanan dan Kelautan Pemerintah Provinsi Sulut, Manado. 76 hal.

Anonimous 2008. Suhu. Sidik Blog's. Karena anda saya ada, untuk belajar bersama. http://sidikpurnomo.net/pembelajar anfisika/suhu, 2 September 2013.

Anonimous 2013 a. Parameter FisikaKimia-Biologi Penentu Kualitas Air | jujubandung jujubandung.com/.../parameterfisika-kimia-biolog.-14 februari 2013

Anonimous 2013 b.Dampak budidaya ikan terhadap kualitas air : studi kasus budidaya ikanjaring apung di Danau Tondano, Minahasa, Sulawesi

Utarahttp://lontar.ui.ac.id/opac/the mes/libri2/detail.jsp?id=71768\&lok asi=lokal (Download 6 Februari 2013).

Effendi H. 2003. Telaah Kualitas Air Bagi Pengelolaan Sumber Daya dan Lingkunagn Perairan. Kanisius, Yogyakarta

Hutagalung HP. 1997. Metode Analisis Air Laut, Sedimen dan Biota Buku 2. Pusat Peneliian dan Pengembangan Oseanografi. Lembaga Ilmu Pengetahuan. Jakarta.

Irianto, Triweko. 2011. Eutrofikasi Waduk dan Danau: Permasalahan,
Pemodelan dan Upaya

Pengendalian. Litbang Sumber

Daya Air dan Pekerjaan Umum. Bandung.

Kordi G, Tancung AB. 2005. Pengelolaan Kualitas Air Dalam Budidaya Perairan. Rineka Cipta. Jakarta.

Kordi KM Ghufran. 2009. Budidaya Perairan Buku Kedua. Citra Aditya Bakti, Bandung.

Kambey RP. 2011. Analisis Parameter fisika Kimia Kualitas Air Pada Lokasi Budidaya Ikan di Danau Tondano Kecamatan Remboken Kabupaten Minahasa. Universitas Sam Ratulangi. Manado.

Mamangkey, Soeroto. 2010. Danau Tondano Surga Para Aliens. Peneliti dan Pengajar Fakultas Perikanan dan Ilmu Kelautan, Unsrat.

Mahida, U.N, 1992. Pencemaran air dan Pemanfaatan Limbah industri. CV. Rajawali. Jakarta. 543 hal.

Nasution S. 2001. Metode Research (Penelitian Ilmiah). Penerbit Bumi Aksara, Jakarta.

Notodarmojo, suprihanto. 2005. Pencemaran Air Tanah dan Tanah. Bandung. ITB.

Anonymous c. 2013. Parameter FisikaKimia-Biologi Penentu Kualitas Air jujuban dung juju bandung.com/.../parameter-fisikakimia-biolog... - (Download 14 februari 2013).

Pacini VA, Ingallinella AM., Sanguinetti G. 2005. Removal of Iron and Manganese Using Biological Rughing Up Flow Filtration Technology. Water Research, 39 : 4463-4475. 